\title{
Keputusan Pekerja Lansia tetap Bekerja Pascapensiun dan Kaitannya dengan Kebahagiaan
}

\section{The Decision of the Elderly to Continue Working Post-Retirement and Its Relation to the Happiness}

\author{
Jamalludin Jamalludin \\ Fakultas Ekonomi dan Bisnis, Universitas Indonesia, Kota Depok \\ e-mail korespondensi:jamall@bps.go.id
}

\begin{tabular}{|l|}
\hline Info Artikel \\
\hline Riwayat Artikel : \\
Diterima: 30 Juni 2020 \\
Disetujui: 24 Agustus 2020 \\
Dipublikasikan: Januari 2021 \\
\hline Nomor DOI \\
10.33059/jseb.v12i1.2450 \\
Cara Mensitasi : \\
Jamalludin, J. (2021). \\
Keputusan pekerja lansia tetap \\
bekerja pascapensiun dan \\
kaitannya dengan \\
kebahagiaan. Jurnal Samudra \\
Ekonomi dan Bisnis, 12(1), \\
89-101. doi: 10.33059/jseb. \\
v12i1.2450.
\end{tabular}

\begin{abstract}
Abstrak
Penelitian ini bertujuan untuk mengetahui kontribusi jaminan pensiun, kebutuhan kesehatan, dan tipe pekerjaan terhadap keputusan pekerja lansia untuk tetap bekerja pascapensiun dan kaitannya dengan kebahagian. Hasil Indonesian Family Life Survey (IFLS) 2007 dan IFLS2014 digunakan sebagai data, dengan unit analisis pekerja usia 52-65 tahun di tahun 2007. Analisis yang digunakan adalah regresi logistik biner dan Wilcoxon sign rank-test. Jaminan pensiun dan bekerja di tipe pekerjaan dengan tuntutan konsentrasi yang besar berpengaruh negatif terhadap kecenderungan lansia untuk tetap bekerja. Kebutuhan perawatan kesehatan yang tercukupi dan bekerja di tipe pekerjaan dengan tuntutan fisik yang besar berpengaruh positif teradap kecenderungan lansia bekerja. Ada perbedaan tingkat kebahagiaan lansia pada saat masih aktif bekerja dengan pada saat sudah tidak bekerja.
\end{abstract}

Kata Kunci: Lansia, Bekerja Pascapensiun, Kebahagiaan.

\begin{tabular}{|l|}
\hline Article Info \\
\hline Article History : \\
Received: 30 June 2020 \\
Accepted: 24 August 2020 \\
Published: January 2021 \\
\hline DOI Number : \\
10.33059/jseb.v12i1.2450 \\
How to cite : \\
Jamalludin, J. (2021). \\
Keputusan pekerja lansia tetap \\
bekerja pascapensiun dan \\
kaitannya dengan \\
kebahagiaan. Jurnal Samudra \\
Ekonomi dan Bisnis, 12(1), \\
89-101. doi: 10.33059/jseb. \\
v12i1.2450.
\end{tabular}

This study aims to determine the contribution of pension insurance, health needs, and type of work to the decision of elderly workers to continue working post-retirement and its relationship with happiness. The Indonesian Family Life Survey (IFLS) 2007 and IFLS 2014 were used as data, with an analysis unit of workers aged 52-65 years old in 2007. The analysis used is binary logistic regression and the Wilcoxon sign rank test. Pension insurance and work in the type of work with a large concentration demands a negative effect on the tendency of the elderly to continue working. Health care needs are fulfilled and work in the type of work with great physical demands has a positive effect on the tendency of the elderly to work. There is a difference in the level of happiness in the elderly when they are still actively working with when they are not working.

Keywords: Elderly, Post-Retirement Work, Happiness. 


\section{PENDAHULUAN}

Pekerja lansia memiliki kesempatan untuk tidak bekerja dan menikmati leisure di masa pensiunnya. Sebanyak 49,39 persen lansia di Indonesia pada tahun 2019 masih aktif bekerja, sementara kebutuhan lansia atas leisure mengalami peningkatan. Penelitan ini bertujuan menganalisis penyebab pekerja lansia masih tetap bekerja di masa pensiunnya dan kebahagiaan lansia ketika sudah tidak bekerja di masa pensiunnya.

Penelitian mengenai keputusan pekerja lansia untuk tetap bekerja di masa pensiunnya sudah banyak dilakukan di luar negeri. Berglund et al. (2017) meneliti mengenai faktor yang memperlama seorang pekerja lansia untuk tetap bekerja meski sudah pensiun. Larsen \& Pedersen (2013) meneliti mengenai aktivitas pekerja lansia pasca usia 60 tahun antara bekerja atau pensiun. Penelitian di Indonesia mengenai pekerja lansia banyak terfokus mengenai determinan lansia bekerja dan determinan lansia bekerja menurut lapangan usaha, selain itu data yang digunakan seringkali data kerat lintang yang kurang kuat menangkap fenomena kausalitas. Penelitian ini mencoba memperkaya riset mengenai lansia dan ketenagakerjan dengan menggunakan data panel IFLS, berfokus kepada pekerja lansia usia 52-65 tahun, dan mengaitkannya dengan kebahagiaan.

Indonesia mulai memasuki kondisi aging population pada tahun 2020, ditandai dengan persentase penduduk usia 60 tahun ke atas yang sudah mencapai 10,06 persen (United Nations, 2019). Proyeksi United Nations menunjukkan persentase penduduk lansia akan mencapai angka 21 persen di tahun 2050. Usia harapan hidup yang meningkat dan penurunan fertilitas menjadi pemicu terjadinya aging population pada suatu negara (Adioetomo et al., 2018).

Implikasi dari peningkatan penduduk usia tua dan penurunan angka fertilitas adalah menurunnya rasio daya dukung (potential support ratio). Rasio daya dukung Indonesia pada 2020 sebesar 11, yang artinya 11 orang usia produktif akan menanggung 1 orang lansia. Jika dalam lingkup keluarga atau rumah tangga, rasio daya dukung dapat di lihat dari perbandingan antara anggota rumah tangga usia lanjut dengan anggota rumah tangga usia produktif.

Rendahnya daya dukung terhadap lansia dapat mendorong lansia untuk masuk kembali dalam pasar kerja. Adioetomo et al. (2018) membagi lansia yang bekerja menjadi dua kategori, yang pertama karena keharusan untuk memenuhi kebutuhan, dan yang kedua karena pilihan sendiri untuk aktulisasi diri mengisi waktu luang. Data BPS menunjukkan pada tahun 2019, satu dari dua lansia di Indonesia masih aktif bekerja dan 16,72 persen diantaranya berasal dari usia 80 tahun ke atas. Jika usia 80 tahun ke atas masih aktif bekerja, maka patut diduga bahwa aktivitas bekerja yang dilakukan untuk memenuhi kebutuhan hidup bukanlah sekedar mengisi waktu luang (Adioetomo et al., 2018). Jaminan pensiun di hari tua menjadi instrumen yang penting untuk menjaga kualitas hidup lansia sehingga tidak terpaksa masuk ke dalam pasar kerja, tetapi hanya sekitar 10,10 persen lansia di Indonesia yang memiliki jaminan pensiun.

Kebutuhan akan leisure meningkat seiring dengan bertambahnya usia pekerja (Wise \& Lumsdaine, 2019). Penurunan upah, dan produktifitas pada pekerja lansia mendorong tingginya permintaan terhadap leisure. Hasil studi milik Friedberg (2000) menunjukkan leisure sebagai barang normal dari pekerja usia lanjut. Peningkatan besaran pensiun dinilai cenderung akan mengurangi kesediaan waktu lansia untuk bekerja.

Morrison (1986) di dalam studinya menjelaskan bahwa lansia tetap memilih bekerja untuk menjaga eksistensinya dalam 
lingkungan sosial. Berhenti bekerja pada lansia menghadirkan perasaan tidak lagi dihargai dan dibutuhkan oleh lingkungan sosialnya. Berhenti bekerja dianggap sebagai hukuman ketimbang kesempatan mewujudkan tujuan baru dalam kehidupan pascapensiun.

Permasalahan lansia menjadi menarik untuk dicermati. Kebutuhan akan leisure meningkat seiring dengan bertambahnya usia dan menurunnya kesehatan, tetapi di sisi lain perasaan terpinggirkan dan tidak dibutuhkan menggerakan lansia untuk aktif bekerja (Wise \& Lumsdaine, 2019; Adioetomo et al., 2018). Lansia yang tidak memiliki nonlabor income seperti jaminan pensiun juga terpaksa bekerja untuk memenuhi kebutuhannya, meskipun dengan tingkat upah yang rendah dan jam kerja yang panjang (Adioetomo et al., 2018). Penelitian UNFPA di 2012 menunjukkan dari 1300 partisipan lansia, sebanyak 53 persen merasa kesulitan untuk memenuhi kebutuhan dasarnya (United Nations Population Fund \& Help Age International, 2012). Indeks Kebahagiaan BPS di 2017 menunjukkan kelompok umur lansia sebagai kelompok umur yang paling tidak bahagia di antara kelompok umur yang lain, hal ini sejalan dengan kompleksitas masalah yang dihadapinya (Badan Pusat Statistik, 2017).

Penelitian ini berfokus menganalisis kontribusi jaminan pensiun, kebutuhan kesehatan serta karakteristik pekerjaan terhadap keputusan bekerja kembali pada pekerja yang sudah menginjak usia pensiun. Penelitian ini mencoba menggunakan data longitudinal IFLS tahun 2007 dan 2014, sehingga dapat diketahui prediktor tujuh tahun kedepan saat pekerja menginjak usia pensiun, apakah tetap bekerja atau tidak bekerja. Keputusan bekerja pada lansia juga akan dikaitkan dengan kebahagiaan lansia, sehingga bisa diketahui apakah ada perbedaan kebahagiaan antara lansia saat aktif bekerja dengan saat tidak lagi bekerja.

\section{Landasan Teori dan Pengembangan Hipotesis}

Peneliti sosiologi dan behavioural science di abad ke-20 mendefinisikan penduduk lanjut usia adalah penduduk yang telah menginjak usia pensiun yang ditetapkan pemerintah (Roebuck, 1979). UNFPA mendefinisikan penduduk lanjut usia di negara berkembang adalah mereka yang sudah menginjak usia 60 tahun ke atas (United Nations Population Fund \& Help Age International, 2012). Adioetomo et al. (2018) menjelaskan bahwa peningkatan kondisi kesehatan menjadikan lansia yang saat ini berusia 65 tahun, kondisinya sama dengan lansia yang berumur 50 tahun pada generasi pendahulunya.

Keputusan seseorang masuk dalam pasar tenaga kerja atau tidak sangat bergantung pada reservation wage yang dimiliki (Borjas, 2010). Jika tingkat upah yang ditawarkan melebihi reservation wage yang dimiliki, maka seseorang akan masuk ke dalam pasar tenaga kerja. Ketika tingkat upah yang ditawarkan lebih rendah dari reservation wage, seseorang akan lebih memilih leisure dibandingkan opsi bekerja. Mereka yang memiliki reservation wage, cenderung lebih kecil kemungkinannya untuk bekerja.

Nonlabor income yang dimiliki seorang pekerja, menjadi pertimbangannya dalam menentukan jumlah jam kerja dan leisure yang dimiliki. Penelitian Friedberg (2000) mengenai efek pendapatan jaminan sosial terhadap kondisi penawaran tenaga kerja, menunjukkan peningkatan uang jaminan sosial menjadikan pekerja mengurangi jam kerjanya. Kesimpulan dari penelitiannya adalah secara umum pengurangan jaminan sosial akan meningkatkan partisipasi tenaga kerja. Jika ditarik ke dalam konteks pekerja lansia, ketika jaminan pensiun/hari tua yang berperan sebagai nonlabor income cukup tinggi, maka partisipasi pekerja lansia rendah. 
Pekerja di akhir masa kerjanya akan memilih untuk tidak bekerja selepas pensiun, ketika memiliki sumber daya yang cukup untuk memenuhi kebutuhan hidupnya (Von Bonsdorff et al., 2009). Kondisi kesehatan juga memainkan peran dalam keputusan bekerja lansia, mereka yang tetap sehat di usia lanjut cenderung memutuskan tetap bekerja dibandingkan menikmati masa pensiunnya (Mutchler et al., 1997). Beberapa variabel sosial demografi yang berhubungan negatif dengan keputusan bekerja lansia antara lain, usia, pendidikan, keberadaan pasangan yang sehat, dan jumlah anggota rumah tangga (Evers \& Ester, 2013; Hansson et al., 1997; Henkens, 1999; Radl, 2013; Ropik, 2013).

Karakteristik, motivasi, dan kepuasan akan pekerjaan mendorong pekerja usia lanjut untuk tetap bekerja dibandingkan pensiun (Larsen \& Pedersen, 2013). Pekerjaan yang sifatnya tidak membutuhkan kekuatan fisik cenderung membuat pekerja lansia memilih tetap ingin bekerja. Lingkungan kerja yang nyaman mendorong pekerja menjadi memiliki kepuasan dan loyalitas terhadap pekerjaanya (Masyitah \& Eliana, 2019). Pekerja lansia yang memiliki kepuasan maupun loyalitas terhadap pekerjaanya cenderung tetap bekerja di usia yang lanjut (Berglund et al., 2017). Keinginan untuk tetap eksis di dalam lingkungan pergaulan dan menjaga identitas diri sebagai orang yang berpengaruh mendorong seorang lansia untuk tetap ingin bekerja (Morrison, 1986).

World Health Organization (2002) memformulasikan konsep active aging untuk meningkatkan kualitas hidup lansia. Active aging yang dimaksud yaitu proses optimisasi kesempatan untuk meningkatkan kesehatan, partisipasi, dan keamanan lansia. Kata "aktif" merujuk pada keterlibatan secara kontinu dalam lingkungan sosial, ekonomi, budaya, spiritual, dan tidak hanya terkait aktif dalam partisipasi kerja. Konsep yang ditawarkan WHO, setidaknya terdapat enam faktor yang membuat lansia aktif, diantaranya layanan sosial dan kesehatan, behaviour, lingkungan, karakteristik personal, kondisi ekonomi, dan kondisi sosial.

Keberadaan anak dalam rumah mampu meningkatkan kebahagiaan lansia (Qian \& Qian, 2015). Keberadaan anak bisa dipandang sebagai bentuk dukungan sosial kepada orang tua, selain itu dapat juga dipandang sebagai jaminan hari tua nonformal. Hasil studi Qian \& Qian (2015) menunjukkan faktor-faktor bertambahnya usia, rendahnya pendidikan, dan kesehatan yang buruk berpengaruh negatif atas kebahagiaan lansia. Kebahagiaan lansia dari sisi ekonomi dapat dilihat dari kemiskinan relatif, yaitu mereka yang merasa lebih miskin dari tetangganya cenderung akan merasa tidak bahagia dibandingkan mereka yang merasa sama bahkan lebih kondisi ekonominya daripada tetangga sekitar (Gray et al., 2008).

Berdasarkan tinjauan literatur dan studi empiris penelitian sebelumnya, dua hipotesis dibangun untuk diajukan dalam penelitian ini.

- Jaminan pensiun (nonlabor income), pekerjaan yang menuntut tenaga fisik, kemampuan memenuhi kebutuhan kesehatan, dan pekerjaan dengan stressor yang tinggi memiliki pengaruh negatif terhadap keputusan pekerja lansia untuk tetap bekerja pascapensiun.

- Kepuasan kerja, dan pekerjaan yang menuntut konsentrasi yang tinggi berpengaruh secara positif terhadap keputusan pekerja lansia untuk tetap bekerja pascapensiun.

Berdasarkan pengembangan hipotesis, rancangan kerangka pemikiran yang menunjukkan jalur hubungan antar variabel yang dianalisis bisa dibangun (Gambar 1). 


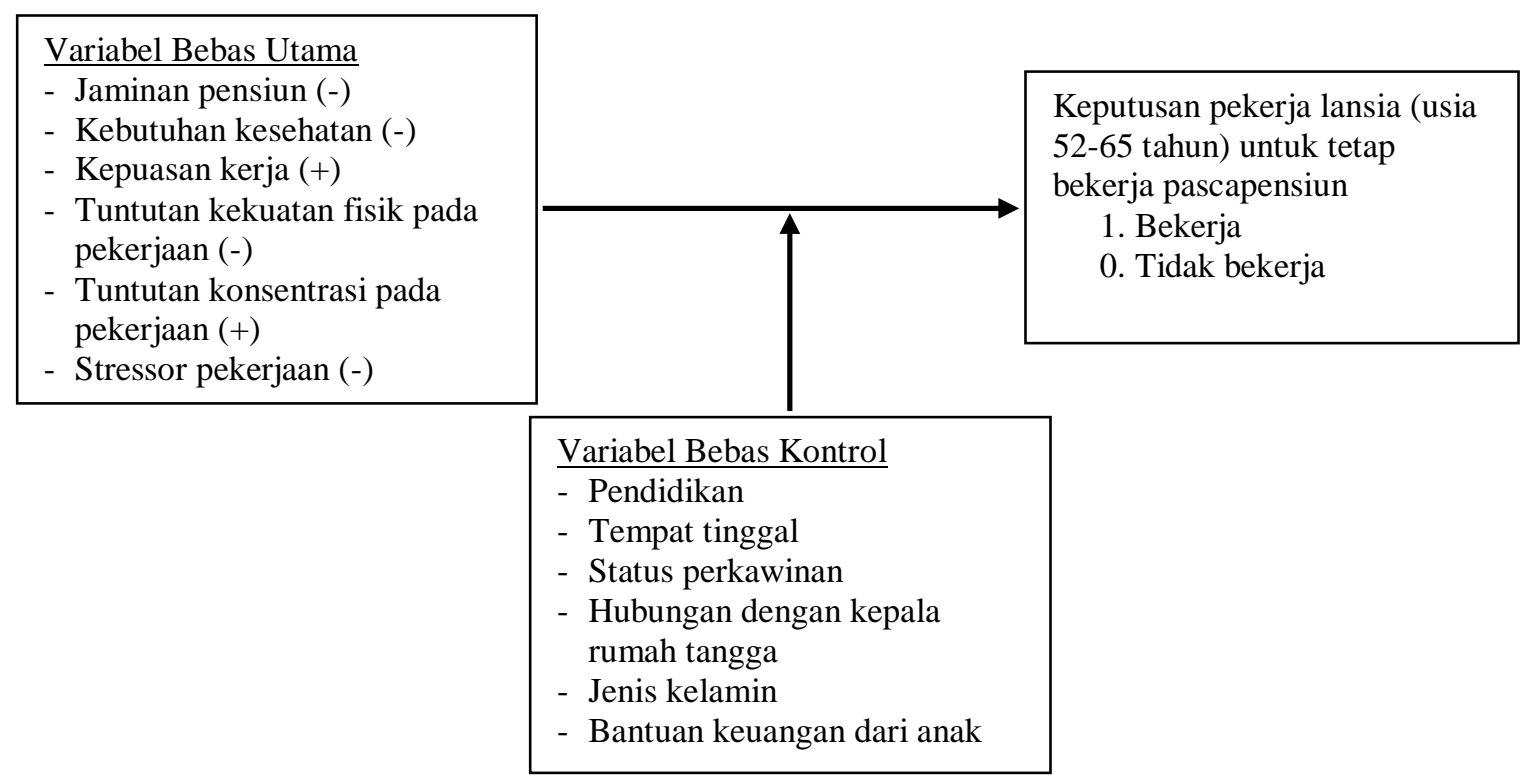

\section{Gambar 1. Kerangka Pemikiran}

Sumber: Diolah penulis, 2020.

\section{METODE PENELITIAN}

Data yang digunakan dalam penelitian ini adalah data sekunder yang bersumber dari IFLS. IFLS yang digunakan merupakan gelombang 4 (tahun 2007) dan gelombang 5 (tahun 2014). Alasan penggunaan data IFLS adalah penelitian ini ingin mengamati sampel yang sama pada dua titik, dengan unit analisis adalah pekerja usia lanjut dalam rentang usia 52-65 tahun. Kelompok umur ini digunakan karena 7 (tujuh) tahun kemudian (tahun 2014) para pekerja tersebut akan memasuki masa pensiun. Dari hasil filter data, responden yang memenuhi kriteria penelitian ini sebanyak 2.047 orang.

Variabel regressan adalah status bekerja lansia, yang mana dikelompokkan menjadi 2 kategori, yaitu 1 untuk bekerja dan 0 untuk tidak bekerja. Variabel regressan ini merupakan kondisi responden pada tahun 2014. Variabel regresor yang digunakan, keseluruhannya berasal dari IFLS 2007. Variabel regressor utama dalam peneitian ini adalah jaminan pensiun, kepuasan kerja, karakteristik pekerjaan (membutuhkan kekuatan fisik, membutuhkan konsentrasi, menimbulkan stress) dan kecukupan kebutuhan kesehatan. Variabel regressor utama ini akan dikontrol oleh variabel umur, jenis kelamin, status perkawinan, pendidikan, jam kerja, hubungan dengan KRT, dan tuntutan pekerjaan. Penelitian ini juga akan mengamati perbedaan kebahagiaan lansia yang pada tahun 2007 masih aktif bekerja, sementara pada tahun 2014 sudah tidak lagi aktif bekerja.

Metode analisis yang digunakan adalah analisis deskriptif dan analisis inferensia. Analisis deskriptif yang disajikan berupa grafik, tabel dan unadjusted odds ratio. Analisis inferensia yang digunakan adalah regresi logistik biner dan Wilcoxon sign-rank test. Regresan pada penelitian ini berupa data kategorik dengan dua kategori, menjadikan analisis yang tepat digunakan adalah regresi logistik biner (Nachrowi \& Usman, 2002). Regresi logistik biner digunakan untuk mengetahui probabilitas atau kecenderungan (Nachrowi \& Usman, 2002) seorang pekerja di usia lanjut pada tahun 2007 untuk tetap bekerja 7 tahun mendatang. Model regresi logistik biner yang diajukan dalam penelitian ini adalah: 


$$
\begin{aligned}
\operatorname{Ln} \frac{\pi}{1-\pi}= & \alpha_{0}+\alpha_{1} \text { Pensiun }+\alpha_{2} \text { Kesehatan } \\
& +\alpha_{3} \text { Kepuasan }+\alpha_{4} \text { Stressor } \\
& +\alpha_{5} \text { TuntutFisik } \\
& +\alpha_{6} \text { TuntutKonsentr } \\
& +\sum_{i=7}^{12} \alpha_{i} x_{i}
\end{aligned}
$$

dimana, $\alpha_{\mathrm{i}}$ adalah koefisien regresi variabel kontrol, dan $x_{\mathrm{i}}$ adalah variabel kontrol.

Analisis Wilcoxon sign-rank test dua sampel berpasangan merupakan metode uji statistik nonparametrik, digunakan untuk menguji kesamaan nilai tengah dari dua populasi berpasangan. Prosedur pengujian test ini setara t-test pada metode parametrik (Riyanto \& Wikarya, 2018). Penelitian ini menggunakan Wilcoxon sign rank test untuk melihat apakah ada perubahan tingkat kebahagiaan dari lansia yang bekerja di tahun 2007 namun tidak bekerja lagi di tahun 2014 . Metode non-parametrik dipilih karena skala kebahagiaan pada penelitian ini adalah skala Likert, dimana 1 untuk kategori sangat tidak bahagia dan 4 untuk kategori sangat bahagia.

\section{HASIL ANALISIS}

Hubungan bivariat antara masingmasing regresor terhadap regresan disajikan dalam tabulasi silang pada Tabel 1, yang menghasilkan nilai unadjusted odds ratio.

Jenis pekerjaan yang tidak memicu stress dan relatif tidak membutuhkan banyak konsentrasi cenderung membuat pekerja usia 52-65 tahun tetap bekerja tujuh tahun kedepan. Pekerja usia lansia yang memiliki karakteristik pekerjaan tidak memicu stress cenderung bersikap untuk tetap bekerja meski memasuki usia pesiun sebesar 1,05 kali lebih tinggi dibandingkan pekerja usia lansia dimana karakteristik pekerjaannya memicu stress sebelum dikontrol variabel lain. Pekerja lansia yang karakteristik pekerjaannya tidak membutuhkan banyak konsentrasi cenderung 1,34 kali lebih tinggi untuk tetap bekerja di masa pensiun dibandingkan pekerja lansia yang karakteristik pekerjaannya membutuhkan relatif lebih banyak konsentrasi, sebelum dikontrol variabel lain.

\section{Tabel 1. Karakteristik Lansia menurut Variabel Utama}

\begin{tabular}{lcc}
\hline \multicolumn{1}{c}{ Karakteristik Variabel } & Bekerja (\%) & Tidak Bekerja (\%) \\
\hline Jaminan Pensiun : & & \\
- Memiliki & 48,43 & 51,57 \\
- Tidak memiliki & 73,58 & 26,42 \\
Kebutuhan Kesehatan : & & \\
$\quad$ - Tidak mencukupi & 68,27 & 31,73 \\
- Mencukupi & 72,90 & 27,10 \\
Kepuasan Kerja : & & \\
- Puas & 72,66 & 27,34 \\
- Tidak puas & 67,45 & 32,55 \\
Tuntutan Kekuatan Fisik : & & \\
$\quad$ - Butuh banyak tenaga & 76,91 & 23,09 \\
- Tidak butuh banyak tenaga & 65,86 & 34,14 \\
Tuntutan Konsentrasi : & & \\
- Butuh banyak konsentrasi & 68,27 & 31,73 \\
- Tidak butuh banyak konsentrasi & 74,26 & 25,74 \\
Stressor : & & \\
$\quad$ - Memicu stress & 71,01 & 28,99 \\
- Tidak memicu stress & 72,04 & 27,96 \\
\hline
\end{tabular}

Sumber: Data sekunder diolah, 2020. 


\section{Ingin menghabiskan waktu lebih banyak} dengan keluarga

Tidak menyukai pekerjaan

Ingin melakukan hal lain

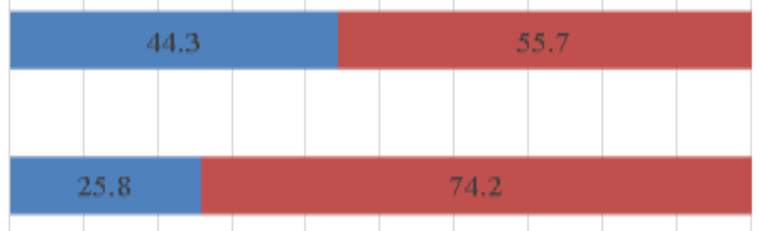

Kesehatan yang memburuk

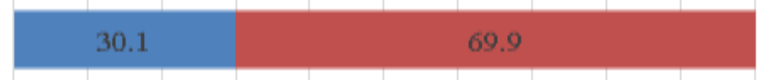

$$
\text { - Penting } \quad \text { Tidak penting }
$$

\section{Gambar 1. Alasan Pekerja Lansia Berhenti Bekerja}

Sumber: Data sekunder diolah, 2020.

Pekerja lansia yang memiliki rasa puas terhadap pekerjaan yang digeluti cenderung tetap bertahan untuk bekerja di masa pensiun. Sebelum dikontrol variabel lain, kecenderungan pekerja lansia yang memiliki rasa puas terhadap pekerjaan yang digeluti untuk tetap bertahan kerja di masa pensiun sebesar 1,28 kali lebih tinggi dibandingkan lansia yang tidak memiliki rasa puas terhadap pekerjaan.

Karakteristik pekerjaan yang membutuhkan tenaga fisik cenderung membuat pekerja lansia untuk tetap bekerja di masa pensiun. Perbedaan peluang antara pekerja lansia yang karakteristik pekerjaanya yaitu membutuhkan tenaga fisik dengan pekerja lansia yang karakteristik pekerjaanya tidak membutuhkan tenaga fisik untuk tetap bekerja di masa pensiun sebesar 11,05 persen. Sebelum dikontrol oleh variabel lain, pekerja dengan karakteristik pekerjaan membutuhkan tenaga fisik cenderung 1,72 kali lebih tinggi untuk tetap bekerja di masa pensiun dibandingkan yang karakteristik pekerjaannya tidak membutuhkan banyak tenaga fisik.

Analisis secara deskriptif juga menghasilkan temuan mengenai alasan yang mendorong pekerja lansia untuk berhenti dari pekerjaannya. Gambar 1 menunjukkan bahwa faktor kesehatan menjadi hal yang dianggap penting oleh pekerja lansia, yang mendorongnya untuk berhenti bekerja. Sebanyak 65 persen pekerja lansia menganggap alasan kesehatan yang memburuk adalah sesuatu yang penting sehingga mereka memutuskan untuk berhenti bekerja. Pekerja lansia yang menganggap alasan ingin menghabiskan waktu luang bersama keluarga sebagai suatu hal yang penting sebesar 44,3 persen. Tidak menyukai pekerjaan dan ingin melakukan hal lain merupakan dua alasan yang dianggap tidak penting oleh pekerja lansia untuk memutuskan berhenti bekerja.

Estimasi model logit yang disajikan dalam Tabel 2 menunjukkan bahwa jaminan pensiun memiliki pengaruh negatif terhadap keputusan pekerja lansia untuk tetap bekerja pascapensiun (sesuai hipotesis), dengan signifikansi sebesar 1 persen. Tipe pekerjaan yang relatif menuntut banyak tenaga fisik berpengaruh positif terhadap keputusan lansia tetap bekerja pascapensiun (tidak sesuai hipotesis). 
Tabel 2. Temuan Model Logit

\begin{tabular}{|c|c|c|c|}
\hline Karakteristik Variabel & Coef. (B) & Signifikansi & Odds Ratio \\
\hline \multicolumn{4}{|c|}{ Variabel Utama } \\
\hline $\begin{array}{l}\text { Jaminan Pensiun: } \\
\text { - Memiliki } \\
\text { - Tidak memiliki (ref) }\end{array}$ & $-0,934$ & $0,000^{* *}$ & 0,393 \\
\hline $\begin{array}{l}\text { Kebutuhan Kesehatan : } \\
\text { - Tidak mencukupi } \\
\text { - Mencukupi (ref) }\end{array}$ & $-0,320$ & $0,016^{*}$ & 0,726 \\
\hline $\begin{array}{l}\text { Kepuasan Kerja : } \\
\quad \text { - Puas } \\
\text { - Tidak puas (ref) }\end{array}$ & 0,373 & $0,015^{*}$ & 1,452 \\
\hline $\begin{array}{l}\text { Tuntutan Kekuatan Fisik: } \\
\text { - Butuh banyak tenaga } \\
\text { - Tidak butuh banyak tenaga (ref) }\end{array}$ & 0,322 & $0,003^{* *}$ & 1,380 \\
\hline $\begin{array}{l}\text { Tuntutan Konsentrasi : } \\
\text { - Butuh banyak konsentrasi } \\
\text { - Tidak butuh banyak konsentrasi (ref) }\end{array}$ & $-0,251$ & $0,026^{*}$ & 0,778 \\
\hline $\begin{array}{l}\text { Stressor : } \\
\quad \text { - Memicu stress } \\
\text { - Tidak memicu stress (ref) }\end{array}$ & $-0,160$ & 0,569 & 0,852 \\
\hline
\end{tabular}

\section{Variabel Kontrol}

Pendidikan :

- Dasar

0,771

$0,002 * * *$

- Menengah

0,375

0,131

- Tinggi (ref)

Status Perkawinan :

- Belum kawin

- Kawin

- Cerai mati/hidup/pisah (ref)

Tempat Tinggal :

- Kota $-0,306$

- Desa (ref)

Hubungan dengan KRT :

- Kepala rumah tangga

- Lainnya (ref)

Jenis Kelamin :

- Laki-laki

0,771

$0,000 * *$

- Perempuan (ref)

Bantuan Keuangan Anak :
- Menerima
$-0,096$
0,423
0,909
- Tidak menerima (ref)

Catatan: **p $<0,01 ; * \mathrm{p}<0,05$

Sumber: Data sekunder diolah, 2020. 
Tabel 3. Nilai Predicted Probability Pekerja Usia 52-65 Tahun tetap Bekerja Pascapensiun

\begin{tabular}{lc}
\hline \multicolumn{1}{c}{ Karakteristik Variabel } & Predicted Probability \\
\hline Jaminan Pensiun : & 0,484 \\
- Memiliki & 0,736 \\
- Tidak memiliki & \\
Kebutuhan Kesehatan : & 0,683 \\
- Tidak mencukupi & 0,729 \\
- Mencukupi & \\
Kepuasan Kerja : & 0,727 \\
- Puas & 0,675 \\
- Tidak puas & \\
Tuntutan Kekuatan Fisik : & 0,769 \\
- Butuh banyak tenaga & 0,659 \\
- Tidak butuh banyak tenaga & \\
Tuntutan Konsentrasi : & 0,683 \\
- Butuh banyak konsentrasi & 0,743 \\
- Tidak butuh banyak konsentrasi &
\end{tabular}

Sumber: Data sekunder diolah, 2020.

Tabel 4. Hasil Uji Wilcoxon Sign-Test

\begin{tabular}{lccc}
\hline \multicolumn{1}{c}{ Pelaporan Tingkat Kebahagiaan } & Observasi & Statistik Z & Signifikansi \\
\hline Lebih rendah saat berhenti kerja & 74 & $-3,008$ & 0,003 \\
Lebih tinggi saat berhenti kerja & 116 & & \\
Sama & 383 & & \\
\hline
\end{tabular}

Sumber: Data sekunder diolah, 2020.

Temuan menarik lain yaitu kemampuan untuk memenuhi kebutuhan kesehatan terbukti mempunyai pengaruh secara positif terhadap keputusan pekerja lansia tetap bekerja pascapensiun (tidak sesuai hipotesis). Kepuasan kerja terbukti berpengaruh secara positif (sesuai hipotesis), sementara tipe pekerjaan yang menuntut konsentrasi terbukti berpengaruh negatif terhadap keputusan lansia bekerja pascapensiun (tidak sesuai hipotesis). Variabel utama stressor pekerjaan diperoleh tidak berpengaruh signifikan dalam memengaruhi keputusan pekerja lansia untuk bekerja pascapensiun; sementara, arah dari hubungan antara stressor dan keputusan lansia bekerja pascapensiun adalah negatif.

Tabel 3 menunjukkan hasil predicted probability pekerja usia 52-65 tahun untuk tetap bekerja di masa pensiun, setelah di kontrol oleh variabel lain. Hasil ini searah dengan temuan dari analisis tabulasi silang dan temuan logit sebelumnya.

Uji Wilcoxon sign-rank test menunjukkan bahwa ada perbedaan secara nyata antara tingkat kebahagiaan pada saat kondisi mereka masih bekerja di tahun 2007 dengan pada saat kondisi mereka sudah tidak lagi bekerja di tahun 2014.

\section{Pembahasan}

Pekerja usia 52-65 tahun yang bekerja dengan banyak tuntutan fisik memiliki pengaruh positif terhadap probabilitas untuk tetap bekerja di masa pensiun. Lebih jauh, peluang pekerja usia 52-65 tahun yang bekerja pada unit usaha dengan tuntutan fisik yang tinggi berbeda sebesar 38 persen lebih tinggi untuk tetap bekerja dibandingkan 
pekerja usia 52-65 tahun yang bekerja tanpa tuntutan fisik yang tinggi. Mereka yang bekerja dengan tuntutan fisik yang tinggi umumnya bekerja pada jenjang jabatan yang rendah sehingga memiliki nonlabor income yang rendah. Hal ini mendorong mereka untuk tetap bekerja meski memasuki usia pensiun. Jika dinilai dari kondisi kesehatannya, mereka yang terbiasa dengan tuntutan fisik yang tinggi umumnya memiliki kondisi kesehatan yang baik sehingga memungkinkan untuk tetap bekerja di usia pensiun. Hasil penelitian ini tidak sejalan dengan temuan Berglund et al. (2017) yang menunjukkan tuntutan fisik yang tinggi pada pekerjaan mengurangi kemungkinan seseorang untuk tetap bekerja di usia pensiun.

Jenis pekerjaan yang membutuhkan banyak konsentrasi berpengaruh negatif atas probabilitas pekerja usia 52-65 tahun untuk tetap bekerja di usia pensiun. Pekerja usia 5265 tahun yang bekerja pada unit usaha yang membutuhkan banyak konsentrasi dalam pekerjaannya cenderung 0,778 kali lebih rendah untuk tetap bekerja saat memasuki masa pensiun dibandingkan mereka yang bekerja dengan tipe pekerjaan yang tidak membutuhkan banyak konsentrasi. Hal ini berbeda dengan temuan yang menunjukkan bahwa pekerjaan yang lebih mengandalkan kemampuan berfikir mendorong pekerja untuk tetap bekerja meski lewat usia pensiun (Elovainio et al., 2005; Gobeski \& Beehr, 2009). Jika dikaitkan dengan jenis jabatannya, mereka yang bekerja dengan konsentrasi yang tinggi umumnya berada pada level jabatan menengah ke atas, sehingga memiliki jaminan pensiun yang cukup. Mereka memiliki nonlabor income yang tinggi, sehingga kecenderungan untuk tetap bekerja di masa pensiun rendah.

Jika dilihat dari uji Wald maka tiga variabel yang dinilai paling signifikan sebagai prediktor pekerja usia 52-65 tahun tetap bekerja di masa pensiun adalah jenis kelamin, jaminan pensiun, dan pendidikan. Laki-laki lebih cenderung untuk tetap bekerja di masa pensiun dibandingkan perempuan. Hal ini menunjukkan masih mengakarnya budaya patriarki bahwa laki-laki sebagai penanggung jawab kebutuhan rumah tangga sekaligus pencari nafkah utama (Adioetomo et al., 2018). Mereka yang berpendidikan dasar memiliki kecenderungan untuk tetap bekerja di usia pensiun dibandingkan mereka yang berpendidikan tinggi. Mereka yang memiliki pendidikan dasar terserap ke dalam tipe pekerjaan informal yang tidak memiliki jaminan pensiun, sehingga mereka terpaksa bekerja meskipun sudah memasuki usia pensiun (Adioetomo et al., 2018).

Sebanyak 7 dari 10 orang pekerja usia 52-65 tahun yang tidak memiliki jaminan pensiun, tetap bekerja di usia pensiun. Hasil ini menguatkan temuan-temuan sebelumnya bahwa kepemilikan nonlabor income pada lansia mampu mengurangi probabiltasnya untuk tetap bekerja saat usia pensiun. Permasalahan yang dihadapi oleh Indonesia sama seperti negara berkembang lainnya, dimana banyak pekerja lansia yang tidak memiliki jaminan pensiun. Lansia di Srilanka hanya satu dari sepuluh yang menerima jaminan pensiun, dan hal ini mendorong penduduk lansia untuk tetap bekerja meski terserap di sektor informal (Vodopivec \& Arunatilake, 2011).

Mereka yang tidak bekerja di tahun 2014 merasa lebih bahagia dibandingkan pada saat mereka masih bekerja di tahun 2007. Temuan ini sejalan dengan hasil penelitian bahwa kebutuhan akan leisure di usia lanjut semakin meningkat, karena pensiunan yang menikmati waktu luang di usia pensiunnya mampu menurunkan tingkat kecemasan yang mereka rasakan (Kaufman, 1984; Nimrod, 2007). Semakin banyak waktu luang yang dinikmati, semakin besar kebahagiaan yang 
dirasakan pensiunan. Kebahagiaan pada usia lanjut merupakan kombinasi antara partisipasi pada kegiatan sosial dengan aktivitas istirahat yang tenang, sehingga aktivitas bekerja yang penuh dengan stressor memicu kecemasan serta berkurangnya rasa kebahagiaan lansia (Oerlemans et al., 2011).

\section{SIMPULAN}

Pekerja pada usia lanjut cenderung membutuhkan leisure yang lebih banyak. Mereka yang tetap bekerja di usia lanjut lebih cenderung berasal dari pekerja yang tidak memiliki jaminan pensiun, yang sebelumnya bekerja pada tipe pekerjaan yang membutuhkan kekuatan fisik, sebelumnya bekerja pada tipe pekerjaan yang membutuhkan sedikit konsentrasi, tak mampu memenuhi kebutuhan kesehatan, dan merasa puas atas pekerjaan sebelumnya. Pemicu yang membuat lansia tetap bekerja itu, mengindikasikan bahwa keputusan lansia untuk bekerja bukanlah suatu pilihan, tapi keharusan untuk memenuhi kebutuhan hidup. Lansia yang tidak memiliki nonlabor income seperti jaminan pensiun, memaksa diri mereka untuk tetap bekerja. Lansia yang tidak lagi bekerja diperoleh melaporkan adanya peningkatan kebahagiaan dibanding saat mereka masih aktif bekerja.

Pemerintah perlu memainkan peran dalam proses terciptanya penuaan yang sukses. Perluasan cakupan jaminan pensiun dan bantuan sosial untuk lansia diperlukan untuk meminimalisir lansia yang bekerja karena terpaksa. Trade off alokasi anggaran antara investasi modal manusia serta penciptaan lapangan pekerjaan kelompok umur muda dan produktif dengan dana sosial untuk kelompok umur lansia menjadi penting untuk disikapi dengan hati-hati, agar tidak mengorbankan salah satu kelompok umur.

Penelitian ini dirasa memiliki beberapa kelemahan. Unit analisis yang digunakan pada penelitian ini terbatas pada usia 52-65 tahun pada 2007 sehingga hanya menangkap peluang tetap bekerja pada lansia kelompok umur 59-72 tahun. Variabel kesehatan yang digunakan pada penelitian ini hanya sebatas pada kemampuan responden untuk memenuhi kebutuhan perawatan kesehatan, sehingga tidak menangkap secara langsung kondisi kesehatan responden. Pengukuran perbedaan kebahagiaan juga masih terbatas pada uji Wilcoxon sign-rank test, yang mana belum di kontrol oleh variabel lain. Kebahagiaan yang dilaporkan lansia yang pensiun bisa jadi diakibatkan oleh faktor lain, selain tidak lagi aktif bekerja.

Penelitian ini dapat dikembangkan lagi dengan menjadikan variabel kebahagiaan sebagai regressan, dan aktifitas lansia (bekerja atau tidak bekerja) sebagai regressor utama. Perbandingan kebahagiaan antara lansia sebelum dan sesudah bekerja dapat lebih jelas terlihat dengan permodelan difference-indifference dibandingkan hanya Wilcoxon sign-rank test. Penelitian mendatang juga menarik jika dipadukan dengan behavioral economics melalui eksperimen atau game theory sehingga pembahasan keputusan lansia bekerja dapat dilihat dari berbagai sisi, seperti ekonomi, antropologi, dan psikologi.

\section{UCAPAN TERIMA KASIH}

Terima kasih dan penghormatan peneliti ucapkan kepada Ibu DR. Dwini Handayani selaku Ketua Prodi Magister Ekonomi Kependudukan dan Ketenagakerjaan Universitas Indonesia serta Bapak Padang Wicaksono Ph.D selaku dosen mata kuliah Ekonomi SDM dan Ketenagakerjaan.

\section{REFERENSI}

Adioetomo, S. M., Cicih, L. H. M., Asmanedi, \& Toersilaningsih, S. (2018). Menjadi lansia: Antara anugerah dan tantangan. In S. M. Adioetomo \& E. L. Pardede (Eds.). Memetik bonus demografi membangun 
manusia sejak dini ( $1^{\text {st }}$ ed., 295-335). Rajawali Press.

Badan Pusat Statistik. (2017). Indeks kebahagiaan 2017. Badan Pusat Statistik.

Berglund, T., Seldén, D., \& Halleröd, B. (2017). Factors affecting prolonged working life for the older workforce: The Swedish case . Nordic Journal of Working Life Studies, 7(1), 19-36. doi: 10.18291/njwls.v7i1.81396.

Borjas. (2010). Labor economics ( ${ }^{\text {th }}$ ed.). McGraw-Hill/Irwin.

Elovainio, M., Forma, P., Kivimäki, M., Sinervo, T., Sutinen, R., \& Laine, M. (2005). Job demands and job control as correlates of early retirement thoughts in Finnish social and health care employees . Work \& Stress, 19(1), 8492. doi: 10.1080/02678370500084623.

Evers, G., \& Ester, P. (2013). The ageing workforce, human capital and the Bermuda triangle: An interdependent analysis. In Older workers in an ageing society (P. Taylor, Ed.). Edward Elgar Publishing.

Friedberg, L. (2000). The labor supply effects of the social security earnings test. The Review of Economics and Statistics, 82(1), 48-63. doi: 10.1162/003465300 558623.

Gobeski, K. T., \& Beehr, T. A. (2009). How retirees work: Predictors of different types of bridge employment. Journal of Organizational Behavior, 30(3), 401425. doi: 10.1002/job.547.

Gray, R. S., Rukumnuaykit, P., Kittisuksathit, S., \& Thongthai, V. (2008). Inner happiness among Thai elderly. Journal of Cross-Cultural Gerontology, 23(3), 211-224. doi: 10.1007/s10823-0089065-7.

Hansson, R. O., Dekoekkoek, P. D., Neece, W. M., \& Patterson, D. W. (1997). Successful aging at work: Annual review, 1992-1996: The older worker and transitions to retirement . Journal of Vocational Behavior, 51(2), 202233. doi: $10.1006 /$ jvbe.1997.1605.
Henkens, K. (1999). Retirement intentions and spousal support: A multi-actor approach. The Journals of Gerontology. Series B, Psychological Sciences and Social Sciences, 54(2), S63-S73. doi: 10.1093/geronb/54B.2.S63.

Kaufman, J. E. (1984). A study of leisure satisfaction, leisure participation, and patterns of leisure activity in relationship to anxiety levels in retirees. Dissertation Abstracts International Section A: Humanities and Social Sciences, 45(6-A), 1868. Retrieved from https://psycnet.apa.org/record/ 1985-53020-001.

Larsen, M., \& Pedersen, P. J. (2013). To work, to retire - or both? Labor market activity after 60. IZA Journal of European Labor Studies, 2(1), 1-20. doi: 10.1186/2193-9012-2-21.

Masyitah, S. M., \& Eliana. (2019). Model peningkatan loyalitas kerja dosen PTS menggunakan structural equation modeling. Jurnal Samudra Ekonomi dan Bisnis, 10(2), 179-192. doi: 10.33059/jseb.v10i2.1323.

Morrison, M. H. (1986). Work and retirement in an aging society. Daedalus, 115(1), 269-293. American Academy of Arts and Sciences. doi: 10.2307/20025034.

Mutchler, J. E., Burr, J. A., Pienta, A. M., \& Massagli, M. P. (1997). Pathways to labor force exit: Work transitions and work instability. The Journals of Gerontology, Series B, Psychological sciences and social sciences, 52B(1), S4-S12. doi: 10.1093/geronb/52B.1.S4.

Nachrowi, D. N., \& Usman, H. (2002). Penggunaan teknik ekonometri. Rajawali Press.

Nimrod, G. (2007). Retirees' leisure: Activities, benefits, and their contribution to life satisfaction. Leisure Studies, 26(1), 65-80. doi: 10.1080/ 02614360500333937.

Oerlemans, W. G. M., Bakker, A. B., \& Veenhoven, R. (2011). Finding the key to happy aging: A day reconstruction study of happiness. The Journals of 
Gerontology, Series B, Psychological sciences and social sciences, 66B(6), 665-674. doi: 10.1093/geronb/gbr040.

Qian, Y., \& Qian, Z. (2015). Work, familiy, and gendered happiness among married people in urban China. Social Indicators Research, 121(1), 61-74. doi: 10.1007/s11205-014-0623-9.

Radl, J. (2013). Retirement timing and social stratification: A comparative study of labor market exit and age norms in Western Europe. Walter de Gruyter GmbH. doi: 10.2478/9788376560410.

Riyanto, \& Wikarya, U. (2018). Statistika ekonomi dan bisnis ( $1^{\text {st }}$ ed.). Mitra Wacana Media.

Roebuck, J. (1979). When does "old age begin"?: The evolution of the English definition. Journal of Social History, 12(3), 416-428. doi: 10.1353/jsh/12. 3.416 .

Ropik, A. (2013). Faktor-faktor yang memengaruhi lansia bekerja menurut lapangan pekerjaan (Analisis data susenas 2013). Universitas Indonesia.

United Nations. (2019). Population data. World Population Prospect 2019. Retrieved from https://population. un.org/wpp/Download/Standard/Popula tion/.
United Nations Population Fund, \& Help Age International. (2012). Ageing in the twenty-first century: A celebration and a challenge. UNFPA. Retrieved from https://www.unfpa.org/publications/age ing-twenty-first-century.

Vodopivec, M., \& Arunatilake, N. (2011). Population aging and labour market participation of old workers in Sri Lanka. Journal of Population Ageing, 4(3), 141-163. doi: 10.1007/s12062011-9045-5.

Von Bonsdorff, M. E., Shultz, K. S., Leskinen, E., \& Tansky, J. (2009). The choice between retirement and bridge employment: A continuity theory and life course perspective. The International Journal of Aging and Human Development, 69(2), 79-100. doi: 10.2190/AG.69.2.a.

Wise, D. A., \& Lumsdaine, R. L. (2019). Aging and labor force participation: A review of trends and explanations. Aging in the United States and Japan, 7-42. doi: 10.7208/9780226590219003.

World Health Organization. (2002). Active ageing: A policy framework. Retrieved from https://www.who.int/ageing/ publications/active_ageing/en/. 